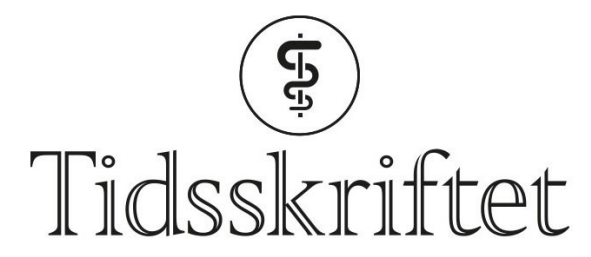

DEN NORSKE LEGEFORENING

\title{
Hvordan best bevare en lever under transplantasjon
}

FRA ANDRE TIDSSKRIFTER

TORBJØRN ØYGARD SKODVIN

Tidsskriftet

Maskinperfusjon istedenfor statisk oppbevaringsløsning reduserte gallegangsskader med over $60 \%$ i en studie.

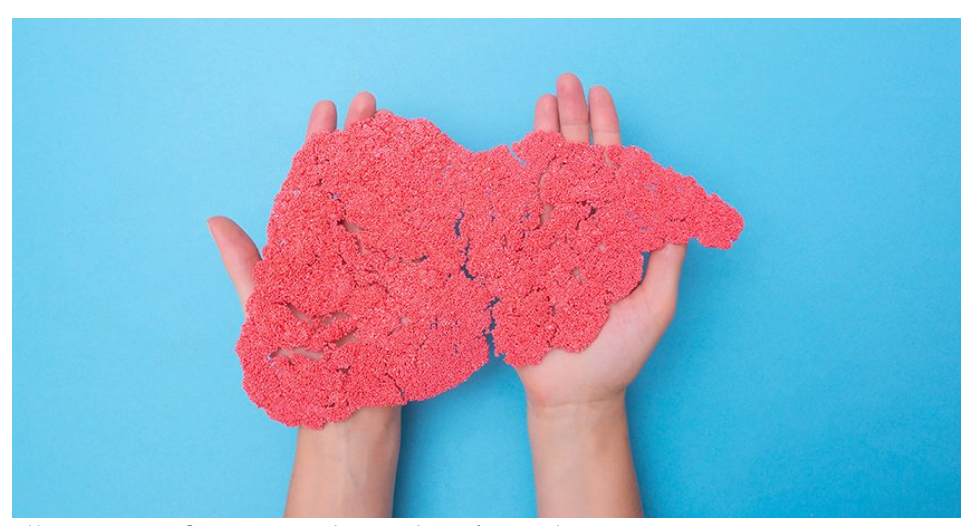

Illustrasjonsfoto: Henadzi Pechan / iStock

Pasienter med langtkommen leversvikt skal vurderes for levertransplantasjon. I tiden mellom uttak og innsettelse lagres leveren i en statisk oppbevaringsløsning. Etter transplantasjonen kan fraværet av normal blodsirkulasjon initialt føre til reperfusjonssyndrom med blodtrykksfall og senere iskemisk skade av gallegangene. I en europeisk randomisert multisenterstudie ble en ny metode for å øke overlevelsen av en transplantert lever undersøkt (1).

78 pasienter ble randomisert til levertransplantasjon med standard metode for lagring av lever. Hos de øvrige 78 pasientene sørget en maskin for perfusjon av oksygenert blod under lagringen. Iskemiske gallegangsskader oppsto hos 14 pasienter ved standard metode, mot fem ved maskinperfusjon, dvs. en reduksjon på over $60 \%(p=0,03)$. Reperfusjonssyndrom oppsto hos henholdsvis $27 \%$ og $12 \%$. Det kumulative antallet terapeutiske intervensjoner de første seks månedene var nesten fire ganger høyere i gruppen som ble levertransplantert med standard metode.

- Dette er en meget interessant og banebrytende studie, sier Pål Dag Line, som er avdelingsleder og professor ved Avdeling for transplantasjonsmedisin, Oslo universitetssykehus.

- Studien er den første til å dokumentere nytten av maskinperfusjon på harde endepunkter. 
Effekten av maskinperfusjon er særlig viktig ved bruk av marginale levertransplantater, sier Line.

\section{LITTERATUR:}

1. van Rijn R, Schurink IJ, de Vries Y et al. Hypothermic machine perfusion in liver transplantation - A randomized trial. N Engl J Med 2021;384: 1391-401. [PubMed][CrossRef]

Publisert: 21. mai 2021. Tidsskr Nor Legeforen. DOI: 10.4045/tidsskr.21.0225

(C) Tidsskrift for Den norske legeforening 2020. Lastet ned fra tidsskriftet.no 